\title{
The Contribution of the Language, Culture and Vision Constructed by Qur'an and Sunnah to the World Peace ${ }^{1}$
}

\author{
Serdar Demirel* \\ Zeynep Havva Kılıç*
}

\begin{abstract}
Many factors bring people together and unite them. Although these factors may have common characteristics in different civilizations and religions, they also have varying attributes. Today, Muslims need a consolidating language, not a divisive one. This is possible only when Muslims have a common language, culture and edifice constructed by revelation. This is crucial for the world peace. Because if peace cannot be achieved in the Muslim world and ethnic problems continue, it will, obviously, threaten regional and global peace. This article is about how Islam provided its followers a common language, culture and edifice constructed by revelation in theory and practice to unite them.
\end{abstract}

\section{Introduction}

Most Muslim countries have multicultural, multilingual and multiracial populations. The given characteristics of the Muslim geography have set a rare example of living together in peace in history.

Islamic revelation has formed the vision of its adherents, the language of this vision and the common culture which emanated from this

1 This paper is originally presented at: Regional Conference on Islam and World Peace organised by Faculty of Usuluddin Sultan Sharif Ali Islamic University, Brunei Darussalam at Rizqun International Hotel, 24-25 February 2010.

* Assistant Professor, Department of Qur'an and Sunnah Studies, KIRKHS, IIUM, Malaysia

* Ph.D Candidate, ISTAC, IIUM, Malaysia. 
discourse by preserving different languages and cultures. This is the reason why the unifying force of monotheism has superseded the divisive force of racism in the Muslim experience of history.

Muslims speaking Arabic, Persian, Kurdish, Malay, Turkish and numerous other languages could preserve their various languages and cultures within the same civilization and act with the reflexes developed by the same vision of the world. Acknowledging the same conceptual world as their reference point, Muslims could realize the dream of a collective, peaceful world despite their differences in language and culture.

The decline of religion under the impact of racist ideological rhetoric instigated by modernity transformed the structure imbued with various cultures and ethnicities from a rich discourse to a battlefield. ${ }^{1}$ The path leading to the future is detached from the past for Muslims sharing the same destiny. The unifying values of religion which should tie yesterday to today and today to the future are enfeebled. Racist ideologies disentangle the bonds of ethical values of Muslim societies and mitigate their will to accept the "other" and live together. Thus, their political decisions are affected in similar ways.

When institutions such as governments and federal organizations emphasising ethnic identities are investigated, it is easily recognized that these associations deliberately target religion, language of the religion and common history. It is not a coincidence that racist associations grudging against each other attempt social engineering using the same kind of tools. The only way to render these attempts vain is to strengthen the values that are being eroded. Muslims need to think of ways to reinforce the vision of religion, language and history, and should establish a common discourse. The sentences Muslims make without using a common language will lead to disintegration. Common language should be created considering the religion, common history and future expectations.

The ethnic problems in the Muslim world can be surmounted using the opportunities emancipating, pluralistic and peaceful nature of Islam has to offer. Hence, through the unifying force of value systems shared by Muslims in general, they can expose the monopolist and addictive character of ideologies which inflame strife among different ethnic. 


\section{Unity Instead of Division}

Many factors bring people together and unite them. Although these factors may have common characteristics in different civilizations and religions, they also have varying attributes. The message of Islam has various distinguishing dimensions. The unique message of Islam transcends the theoretical level and still preserves its feasibility of application despite its debilitation in the Muslim mind inflicted by the effects of modernity.

In spite of this historical experience for many Muslim countries it's difficult to maintain their multi-cultural, multi-ethnic and multi-lingual bodies. Muslim nation states such as Turkey, or other Muslim states undergoing a belated nation-state process like Pakistan, are struggling with ethnic tensions. The Kurdish problem in Turkey, Iran, Iraq and Syria; Balluji problem in Iran and Pakistan; Pashtun problem in Pakistan, Berberi problem in Morocco, Darfour and North problems in Sudan, Tajik problem in Afghanistan are such cases.

Oblivious to its historical experience of unifying different ethnic groups and blending them in a harmonious civilization, the Muslim world expects solutions from the West. If the Muslim World aspires to establish a peaceful, pluralist world by preserving distinctive characteristics of different ethnic entities, it should seek the solution by referring to the origins which constructed its edifice of the world and its historical practice instead of importing quick Western formulas. The historical practice of the Muslim world is reflected in Baghdad, Istanbul, Kudus and Cordoba; cities which nurtured the experience of living together and cradled mosques, churches and synagogues adjacent to each other.

"Living together in peace" refers to justly assigning everyone basic rights and freedom. Hence, the formulas developed by the West can be deemed applicable. Nevertheless, it should be borne in mind that these formulas stemmed from a historical background laden with bloody religious and sectarian clashes. The sectarian wars which claimed the lives of one third of the Western population, materialised the Western legislative form and weakening culture of "living together" as exigency. Not having such a bloody history, the Muslim world cannot import and apply Western solutions to its problems. The nation-state ideology based on exclusion of the "other" and its practices are the roots of the problem plaguing the Muslim countries today. An 
ideological and legislative transformation can curb the ethnic problems in the Muslim world.

Therefore, we should carefully study the ideological foundation and the history offering the experience of unifying different ethnic groups with due respect and honour without alienating them to their origins. The worldview of Man inculcated in this experience is a reference point from which the ethnic problems of today can be curbed.

This study aims to contribute to the solution of this problem by introducing a theoretical framework and experiences related to the Muslim history of tolerance and unity.

\section{The Relation between Islam and Peace}

The concept of "Islamic life" evokes peace, tranquillity and security in the minds of Muslims. The relationship between Islam and peace is ontological and Muslims reflect this equity in their lives by establishing security and peace.

Semantically, Islam means peace, tranquillity, well-being, security and submission. These meanings enrich the worlds of Muslims.

Islam, which derives from the root S-L-M, is not a word chosen by Prophet Muhammad (p.b.u.h) or the adherents of Islam. It is a multilayered word chosen by Allah to refer to this religion and for Muslims, it has a high-esteem.

"This day have I perfected your religion for you, completed My favor upon you, and have chosen for you Islám as your religion"

Of course, there are many reasons why Allah called the religion $\mathrm{He}$ sent to humanity "Islam" and some of these reasons are mentioned in the Quran. All the reasons mark the world this religion aims to construct:

(This will be) their cry therein: "Glory to Thee, O Allah!" And "Peace/Salam" will be their greeting therein! and the close of their cry will be: "Praise be to Allah, the Cherisher and Sustainer of the worlds!"

${ }^{2}$ Al Maida: 5/3. 
Greeting is not meant for Heaven only. The practice of saying "Assalamu alaikum" "Peace be unto you " and responding "Wa alaikum's-salam wa rahmetullahi wa barakatuh" "Peace be unto you and so may the mercy of Allah and His blessings" is exercised in this world as well. ${ }^{3}$ The most visible characteristic of the Muslim society is to gather with the prayer of peace and to leave with the same wishes.

Islam encourages the quest for Salam to be pursued in Allah, the Sustainer of peace and security. Submission to Allah, seeking peace and security from As-Salam (one of the Holy names of Allah) are fundamental for the belief in unity of Allah, and they reflect the meaning of Salam in Man's life to lead him to Jannah, in other words Dar'us Salam (Home of Peace): "But Allah doth call to the Home of Peace: He doth guide whom He pleaseth to a way that is straight."

The eternal abode for the true believers is defined as "Home of Peace". The dwellers of this will be addressed gracefully: "Not frivolity will they hear therein, nor any taint of ill,-Only the saying, 'Peace! Peace'., 5

Peace both in the world and in the hereafter. Peace is essential in the religion of peace, even with enemies: "But if the enemy incline towards peace, do thou (also) incline towards peace, and trust in Allah: for He is One that heareth and knoweth (all things). "6

Allah advises the believers to refrain from following Devil, the worst destructor of peace: "O ye who believe! Enter into Islam wholeheartedly; and follow not the footsteps of the evil one; for he is to you an avowed enemy." 7

Islam advocates peace, tranquillity, security and builds a world on these pillars. The ontological confidence of Man is found on this basis. Man can set an example of living in peace only when he is at peace with Allah, himself, his environment and humanity. Islam moulds the ideological codes of Man to procure this practice since the codes of the mind determine the reflexes of Man.

\section{The Concept of Identity}

The concept of identity in Islam renders racist provocations and discourse meaningless. We shall begin our discussion with this question: What gives Man his identity? "Identity" cannot be defined only on the basis of race or culture. Neither can it be defined 
according to one's taste of rhythm or melody. Racist pursuits of identity have fallen into this error.

The fundamental unifying factors of Islam, however, are "religion, language, culture and history". Identity cannot be defined without these elements. Secular elites alienated to these four essentials address these factors separately and suppose that identity can be described thus. The most determinant factor among all four in shaping identity is, undoubtly, Islam. When we study the conceptions of the Muslim mind we can have a better understanding of this dynamic.

In Muslim societies the main reference source for the Muslim mind is Quran. A reading of identity based on the Quran will reveal three types of identity: common identity, lower identity and unique identity. This is clearly stated in Surah Hujurat:

"O Mankind! We created you from a single (pair) of a male and a female, and made you into nations and tribes, that ye may know each other (not that ye may despise (each other). Verily the most honoured of you in the sight of Allah is (he who is) the most righteous of you. And Allah has full knowledge and is well acquainted (with all things)."

This verse is addressed to all humanity. The emphasis on the phrase "O Mankind!" is very often used in the Quran. Being human is the common identity for the entire Mankind. It encompasses all human beings regardless of their colour, language, culture or place of origin.

Under this common identity there are sub-identities. These subidentities are clans and tribes. All these entities are sub-branches of the common identity and the only reason for the differences among is to enable them to "meet and know" each other. The sub-identities are acknowledged in the Quran on the condition that they should not be a basis to claim superiority. Although sub-identities do not supersede the emphasis of common identity, their significance in unification is not undervalued either because the unification of clans leads to a tribe or the unification of tribes leads to the formation of a nation.

Common and sub identities are not acquired; they are given. They are granted according to Divine Will and Man does not have any authority over the determination of these identities. First Man is assigned his 
common identity as a human being and then he is assigned his subidentity; there is no role of Man's preferences in the determination of these two kinds of identities. Hence, Man cannot be honoured or criticized according to these two identities since they are not acquired but granted by the Divine Will. For these granted identities, Man should only feel gratitude towards the Giver and acknowledge that all these identities are granted by the same source, thus they are all equal.

According to the verse 13 in Surah Hujurat mentioned above, there is another identity: the unique identity. The unique identity is different from the other two identities in the sense that it can be acquired through conscious effort by Man. This identity is found in faith, effort and production. The faith pertains to religions or ideologies. In the Islamic perspective, Man gains his value before Allah and other men according to his choice of faith. All men who choose to believe in Allah, construct their mind according to revelation and organize their life in an Allah-conscious Manner as men of piety regardless of their color, race or religion and therefore they have unique identity.

The verdict in the verse "Verily the most honoured of you in the sight of Allah is (he who is) the most righteous of you" emphasizes the significance of unique identity. Man acquires his value before Allah with this identity he chooses using his mind and free will. A Muslim believing in Surah Hujurat cannot, categorically, harbour animosity towards a particular race.

Despite all the distortions inflicted by racist propaganda on the Muslim mind, the edifice of Muslim identity lies within this verse. The worldview based on this verse enables many races to gather and live in peace in Muslim lands. As races mix, people become relatives through marriage and instead of clash, peace reigns and prospers.

\section{On the Nature of Man}

Tribalism is not only sectarian, separatist and perilous, but it is also inhumane and unIslamic. All Man descended from the same father and mother. Therefore, claiming superiority on the basis of race can only be a sign of his intolerance. The story of Adam's creation is vividly described in the Quran. This description marks the meaninglessness and peril of racism. Allah states that He created Man as His vicegerent on earth: 


\begin{abstract}
"Behold, thy Lord said to the angels: "I will create a vicegerent on earth." They said: "Wilt Thou place therein one who will make mischief therein and shed blood? whilst we do celebrate Thy praises and glorify Thy holy (name)?" He said: "I know what ye know not." 9
\end{abstract}

The most distinguishing feature of Man is crystallized in the word "vicegerent" as Man is the only creation assigned with this privileged role. The answer to the question "Who is the vicegerent and what is the nature of the creature who assumed this role?" is important to reveal the reality of racist propaganda.

The word khalifa (vicegerent) is derived from the root KH-L-F which means a person who is appointed to assume authority and act for someone. When one is appointed as the vicegerent of Allah, this post bestows great honour on its holder. ${ }^{10}$ Vicegerent means a deputy exercising authority, a representative who fulfills the responsibilities of his position.

The first Man, Adam, was created for the mission of acting as a vicegerent of Allah and he was asked to assume this responsibility. His descendants, similarly, are appointed with the same divine responsibility until the Day of Judgment. Children of Adam, like their father, were asked to establish peace and live in harmony, "It is $\mathrm{He}$ Who hath made you (His) agents, inheritors of the earth."11 Obliging to this invitation and living with this mission is a matter of faith. In another verse, Allah says:

"O David! We did indeed make thee a vicegerent on earth: so judge thou between men in truth (and justice): Nor follow thou the lusts (of thy heart), for they will mislead thee from the Path of Allah: for those who wander astray from the Path of Allah, is a Penalty Grievous, for that they forget the Day of Account." 12

Since Man acts as the vicegerent of Allah, reflecting on Allah's authority, he will execute Allah's orders on earth. Thus, the nature of his creation raises as a matter of utmost significance. The Quran informs us that Man is created as a two-dimensional being to carry out this task and he is equipped with supreme qualities. First, Man's material entity, in other words his worldly dimension, was created. The 
main ingredient of the material body of Man is clay which is produced from dry, putrid mud. From the Quranic verses we learn that water is added to the ingredients in clay:

"He it is created you from clay, and then decreed a stated term (for you)."13, "We created Man from sounding clay, from mud moulded into shape"14, "He created Man from sounding clay like unto pottery" 15

As these verses state, the knowledge and wisdom of Allah are reflected in the fact that the initial stage in the creation of Man from clay is produced from putrid mud. The wisdom in clay being the yeast of Man's creation is to show that this aspect of Man bears no significance. Unfortunately, racist ideologies deem this dimension of Man superior. The qualities in this dimension are attributed by the clay such as scalp, blood or skin colour. This is briefly the tragicomic position fascism has put itself into. Knowledge and wisdom of Allah and His art of creation are displayed in the craft of the creating Man from clay.

The story of Man's creation, however, does not end here. Soul is added to the physical dimension of Man to enable him to assume the divine responsibility:

"Who made all things good which He created, and He began the creation of Man from clay; then He made his seed from a draught of despised fluid; then $\mathrm{He}$ fashioned him and breathed into him of His spirit." 16

"Behold, thy Lord said to the angels: "I am about to create Man from clay. When I have fashioned him and breathed into him of My spirit, fall ye down in obeisance unto him."17

Spirit is a sublime, luminous and living being. The dimension which renders Man lofty is inherent in the spirit. The verses above show that the angels present at the scene were ordered to prostrate before Adam only after the spirit was breathed into him. When only the physical dimension of the vicegerent was formed, the angels were not ordered to prostrate before him because he had not deserved either the vicegerency or the prostration yet. It is, therefore, evident that when the spirit was breathed the Man transcended his physical being and gained his divine position. Thus, he deserved the prostration of angels before him. 
In other words, Man could attain his divinity only through his spirit. Allah who created Man breathed him spirit and attributed the spirit to Himself by saying "Breathed into him of My spirit". ${ }^{18}$ This attribution proves that Man has been esteemed as the most honourable and elevated with his spirit like the Baytullah (The House of Allah) is honoured with a similar quality. Similar to Man, Baytullah is attributed to Allah to prove its value for Allah, although Allah is unfettered by space Himself. The spirit grants Man divine qualities such as life, knowledge, sense, hearing and free will. Sublime characteristics are slightly mirrored in Man, a simple creation of clay. The secret of vicegerency lies within this bestowment.

According to the verses, Allah created His vicegerence with two dimensions: his dimension of being created of clay to establish a relationship with worldly beings, and his spiritual dimension to transcend beyond substance and affiliate himself with the metaphysical realm. With his two-dimensional nature, every child is born with a clear conscience. Moral values, on the other hand, are ingrained in Man's nature:

"And $\mathrm{He}$ inspired it (with conscience of) what is wrong for it and (what is) right for it."19

The Prophet's saying denotes the same aspect of the nature of Man: "Every child is born with a true faith (on Fitrah) but his parents convert him to Judaism or to Christianity or to Magainism.",20

The Man referred in the Quran is a being for whom angels prostrated. Is there a humanist doctrine which gives such tremendous credit to Man? The choice whether to maintain his God-given loftiness is left to the free will of Man. The vicegerent of Allah, equipped with the free will inherent in his nature, is sent to the world to determine the value of his being. What is required of him is to fulfil the wishes of his Creator with the qualities granted to him and to exert the practice of living together in peace with his fellow beings. Although superiority can be gained by piety, it will not entail a worldly privilege. All men are equal before law and superiority pertains to only affairs of the hereafter.

\section{The Meaninglessness of Racism}

We have elaborated above how men are equal in terms of their creation. This notion unifies them in a nucleus-family as the belief 
of tawhid instructs. Racist ideologies, however, aim to disintegrate this unity with their doctrines.

Many sources narrate that Noah had three sons named Ham, Sam and Yafes, and Mankind descended from these three brothers. According to the narration of Ibn Kathir, Sam is the father of Arabs, Persians, Romans and the Jews; Ham is the father of all the black people in the East and the West; and Yafes is the father of the Russians, Polishs, Yugoslavians, Serbs, Croats, Czechs, Bulgarians, Slavics and Turks. ${ }^{21}$

Some people regard the differences in races and languages, intended to encourage people to meet and know each other, as means to claim superiority. Racist mentality expounds the race he belongs to as the superior race. This perception leads to discussions of races in terms of superiority. If the narrations are true, we are all descendants of Ham, Sam and Yafes. The meaninglessness of racism lies not in our origin but the irony of Man's claim of racist superiority after tracing his origin to the same family. The ignorant Man does not trace all humanity back to Noah and unify them, but rather divides focus on the trifle ethnic variations. Thus, seeds of hostility and division are sown by preferring a divisive approach to an ethical one.

If we assume the family tree traced back to Noah as incorrect, we still have to face the fact that Islam, Christianity and Judaism all identify Adam and Eve as the first ancestors of Mankind. This doctrine of the origin of Man is one of the common facts of these religions. All the other religions unanimously agree that Mankind descended from the same family.

This religious doctrine has been confirmed with rational evidence and historical perception of society. Should not the concept of "race" be a common ground for the communities of faith? Nevertheless, the racist Man can create a problem out of his predetermined biological lineage

Unfortunately, this problem does not remain only as an irony. It has changed into a devastating tribalism movement which led to intense bloodshed throughout history. No war in history has claimed as many lives as the Second World War sparked by racist ideologies. Hitler idealized the paradigm of "superior race". He shed the blood of millions of people, including his own. At the end of the war, the Man seeking superiority in blood gained nothing but blood. 
Segregating men as descendants of Ham, Sam or Yafes instead of uniting them as children of Adam or Noah is a pernicious trap Man set for himself. Man screen his rationality with his racist sentiments, and thus change into a guile, egocentric being whose only ideology is to dominate and rule others.

Paradoxical as this may seem, the Man who assumes superiority for his racial affiliations does not inherit his superiority from his ancestors. He legitimizes his assumed superiority by emphasising historical belonging. Thus, though their races may differ, the ideologies of the racist do not change. For instance, you can alter the mentioned race in their slogans to Arab, Kurdish, Turkish, German or any other language. The exclusive and divisive racist movements are all nurtured by the same ideology.

\section{Historical Experience}

In the previous chapter the road map of living together purported by revelation has been evaluated. In this chapter we shall provide examples from history to illustrate the practice of living together. Since the abstract doctrines we have mentioned so far may seem complex, we shall concretize our arguments with historical anecdotes. Thus, we shall mention some narrations from the Prophet Muhammad (p.b.u.h) and model behavior of the companions of the Prophet. His narrations and practices of his companions play a consolidative role for most of the Muslim community.

The Prophet prohibited all kinds of racism and declared that superiority among human beings can only be gained by improving the quality of the soul. He underlined this doctrine in his saying: "Verily Allah does not look to your bodies nor to your faces and wealt but He looks to your hearts and deeds." 22 In another version of this narration he has been quoted as saying "he pointed towards the heart with his fingers." 23 as an explanation for "He looks to your hearts".

The Prophet also said: "Mankind will either stop boasting about their ancestors who have turned into nothing but coal for the hellfire, or they will go down to the level of a cockchafer rolling dirt with its nose. Allah has purified you fom the vanity of Jahiliyyah.Then he is either a devout believer or a miserable merchant. All men are children of Adam and Adam was created from clay. ${ }^{124}$ 
Prophet Muhammad defined racist movements and their ideologies as "Jahiliyyah" (ignorance) and informed that those who die for the sake of racism will not be granted mercy by Allah:

"One who is killed under the banner of a Man who is blind (to his just cause), who raises the slogan of family or supports his own tribe (for racism), dies the death of one belonging to the days of Jahiliyya." 25

Since its early periods Islam aims at eradicating racism and tribalism. When the companions of the Prophet are considered, it can easily be observed that they were from various races. His universal message excluded all forms of racism. For example, among his companions, Abu Bakr was an Arab, whereas Bilal was an African from Habashah (nowadays Ethiopia), Suhaib was a Byzantinian and Salman was a Persian. The integrating message of Islam brought them together from different regions and races, and rendered them into the generation of the Golden Era. The universal message of Islam brought them together and this dynamism empowered them to write history. A few remarkable experiences of this generation will clearly elaborate this issue further.

One of the famous and distinguished companions, Salman, was named Mabah b. Buzahsan before he became a Muslim. After he converted to Islam, he was named Salman. His kunyah (referring to the person's first-born son) was Abu Abdullah. When he was asked of his patronymic he answered, "I am Salman, the son of Islam". Later he was called with this title, "Son of Islam" among Muslims and even in books on biographies of reporters he was accorded with the same title. ${ }^{26}$ The edifice materialized in the title "son of Islam" reflects the perception that one's race is determined by his faith, values and belief system. This understanding prioritizes values and belief to race.

Bilal bin Rabah, one of the first to declare belief in the Prophet and later honoured as his muezzin (caller to prayer), was from Ethiopia and he was the slave of one the vain aristocrats of Makkah, Umaiyah bin Khalaf. Being a black Man, he could hold no other status than being a slave. Islam equated him with all other Muslims, regardless of their races or wealth to the extent that Abdurrahman bin Auf from the Ban̄ Zuhra family of the tribe of Quraish married him to his daughter. ${ }^{27}$ 
One of the "mothers of believers" (the wives of the Prophet) was Umm al Mu'minin Safiyyah bint Huyayyay. She was the daughter of the leader of a Jewish tribe, Banī Nadr, in Madinah. ${ }^{28}$

Many of the companions of the Prophet greatly respected had converted to Islam from Judaism. Abdullah bin Salam, formerly Al Hasiyn, from the Jewish tribe Bani Kaynuka can be given as an example. ${ }^{29}$ Moreover, a considerable number of the prophets mentioned in the Quran also came from Jewish tribes. All these examples clearly illustrate that racist doctrines can also be categorized as sinful.

At this point a question arises: What about the condition of nonMuslim races? According to Islamic principles, the ummah (community) of the last prophet, Prophet Muhammad, was the entire humanity. The concept of ummah cannot be confined to a specific race, colour or language. Yes, the entire humanity is his ummah and this ummah is divided into two categories: The first category consists of those who complied with the invitation of Islam. Those who have not responded to the invitation fall into the second category. Therefore, the concept of Islam encompasses all of mankind, invites them to unite, help each other with grace and goodwill, and dissuade each other from committing any evil.

Islam orients itself in unifying the poor and the rich, the white and the black, and the Eastern and the Western. This worldview is constructed with doctrines as well as historical experiences. Even the annual practice of pilgrimage suffices to demonstrate how Islam equates all men.

\section{Freeing the Mind from Colonial Bonds}

The map of the Muslim world today has been drawn based on the era of colonialism. Muslims gradually internalized this division. If the divided nations, however, dream of uniting, would the fragmented map mean anything? Since the political willpower of the Muslim nations will inevitably converge, the prevalent situation is temporary. Masses always believe in this. Victorious forces draw the maps. Their victory, on the other hand, is not eternal. Conjunctures change and bring about political shifts. Maps and borders change and the history is rewritten. 
Believing in the stability of maps can be regarded as superstition and it results in internalization of the status quo. This static perception of history cannot be justified by the nature of Man, the evolving of history or volatile global politics.

Colonialists did not draw the borders only on land, knowing that geographical borders would not last long. They do not have stagnant maps on their minds. They divide to rule and rule to exploit. If their exploitation is somehow hindered, they resort to reshaping borders on the pretext of liberalisation. They imprint their real maps on the minds of the elites of their colonies. Today, they are writing the same scenarios.

The political order for the $21^{\text {st }}$ century has not been established yet. If Muslims are to secure a position in the volatile arena of the $21^{\text {st }}$ century politics, first, they need to concentrate on their unity. To broaden our horizon by innovative political analysis, we need to free our minds from their psychological barriers.

Both the real politics after the collapse of the Ottoman Empire and the aftermath of the Iraq occupation have shown that the welfare, development and peace will not be achieved in the Muslim world with single nations or ethnic groups. Turks, Arabs or Persians cannot be happy without securing the welfare of the Kurdish and vice versa. Peace in the Muslim world can come about only with the happiness of all ethnic communities in the society. Interlocking dreams for the future are the only way out for a peaceful, bloodless future.

\section{Conclusion}

Islam has a firm stance against racism. Racism is divisive and thus it has been prohibited. It fans the flames of hostility among Mankind by turning them against each other.

When we study the Ottoman rule we see a society founded on the concept of "ummah". The Ottoman society was a strong, thick rope threaded with the strings of various races. The racist policies adopted by the Union and the Progress committee incited the plans of the West to divide the Ottoman Empire. This mistake triggered others and the racist inclinations and policies of the Union and Progress committee cultivated sectarian movements in Muslim and nonMuslim communities. When the rope was affected by the nation-state 
ideology and fragmented into small strings, the West did not need to try hard to dominate small groups.

The common memory of the races which moulded their history together for centuries was enfeebled by nation-states. The West tried to achieve this by deteriorating the ethical values of Muslim societies. The sentences enlightened elites utter divide Muslims in despite of their ideological relationship. Muslims need a consolidating language, not a divisive one. This is possible only when Muslims have a common language, culture and edifice constructed by revelation. The need for the theory and practice is urgent.

Islam is a religion of unity. In this religion unification is essential both in religious and social sense by encouraging the perception that all men descend from the same family. Nobody has the liberty of choosing his parents, society, colour or language; they are all predetermined and given. These attributes cannot constitute a ground for superiority or inferiority. Belittling someone for his race is indeed criticizing Allah's creation. Therefore, the racial superiority claims have no rational or ethical basis.

"When the Trumpet is blown, there will be no kinship among them that Day, nor will they ask of one another!"30

If peace cannot be achieved in the Muslim world and ethnic problems continue, it will, obviously, threaten regional and global peace. If Muslim countries are not peaceful, they will have to waste all their resources and social energy in ethnic clashes. If they want to break this vicious circle, the Muslim world should face itself and develop solutions which will suit its social texture. In this context, the theoretical framework set by its historical experience and religion offers considerable opportunities for solution. The results deduced from historical study can be utilized in modern forms. Muslims should not miss this opportunity if they do not want to waste another century. 
1 Nationalism was unheard of in the Muslim World until a century ago. It was imported to the world of Islam through colonialism and elites educated in the West and became "nationalist", "secular" and "westernized". The West divided the Muslim World into nation-states and today its map represents a world where "nationality' stands above Islam."

Ghayasuddin, Muhammad, The Impact of Nationalism on the Muslim World, (London: The Muslim Institute, 1986), vii.

Nationalism emerged as a school of thought after the French Revolution in the West. Nationalism emphasized and sanctified elements which compose national identity such as national flag, anthem, festivals etc. Soon nationalism became popular in Europe and even expanded to other parts of the world, however, devoid of notions of freedom and democracy. Inevitably it became a pseudo-religion using which Western governments could instigate feelings of aggression, corruption and self-interest in European colonies of the Ottoman State.

The first seeds of nationalism on Muslim lands were notably not sown in British or French-ruled areas but in regions under the rule of the Ottoman State. In India, then a British colony, even westernized scholars such as Sir Sayyed Ahmad Khan did not promote the idea of "nationalism" but rather focused on economic and educational development of Muslims.

Naqawi, 'Ali Muhammad, Islam and Nationalism, (Iran: Islamic Propagation Organization, 1984), p.28.

However, outcries for nationalism reverberated in areas such as Egypt, Syria, and Lebanon which were in the realm of the Ottoman State. This situation demonstrated that nationalism was used as a means of shattering the unity of the Muslim World. European authors and Muslim authors educated in Europe played a key role in scattering the Muslim World as Ansari points out:

"It had become very clear to me from the writings of European authors that imperialistic designs of Europe were in great need of this effective weapon- the propagations of the European conception of nationalism in Muslim countries- to scatter the religious unity of Islam"

Ansari, Zafar Ishaq, (1961). Iqbal and Nationalism. Iqbal Review, Lahore, vol. II, No1, 1961, p.68.

Napoleon's invasion of Egypt was a turning point in history in the Muslim World. By establishing the "Egyptian Institution" which supposedly focused on research in ancient Egyptian history and culture, Napoleon could disseminate nationalist ideologies through French scholars who emphasized the grandeur of Egyptian civilization. Many Egyptian scholars educated in the West such as Defa'at al-Tahtavi, Yaghoub Zow'e, Taha Hussein contributed to the Western plans of the West to divide the Ottoman State and Muslim unity by establishing political parties and publishing books in which they promoted nationalism as a means of progress and adopting Western values.

Gradually the Western ideological heritage and culture penetrated the Arab World. Western political thought, including nationalist doctrines were embraced uncritically 
in the Middle East. The fascination with the European intellectual legacy propelled Ottoman provinces to the "idea of reformism"

See, Naqawi, Islam and Nationalism, p. 32.

Nationalism plagued many Arab countries under the domination of the Ottoman State. Apart from Western-educated intellectuals missionaries played a significant role in transformation of the Arab World. Missionaries had settled in Arab countries Syria, Lebanon and Jordan under the faz ade of protecting the rights of Christian Arabs. As their communities grew larger through educational institutions such as Jesuit schools, Maronite and Protestant Colleges their influence in the Ottoman State also grew. Since graduates of these schools were equipped with European languages, they acquired high-ranking positions in the Ottoman State. Consequently, Muslim Arabs realized that in order to meet requirements of high administrative positions they must "acquire some European languages and culture".

See, Osman Ibrahim Bashir, "Islamic Perspectives on the Question of Nationalism and National Integration: The Case of the Sudan", (Ph.D. thesis, University of California, 1984), p. 96.

In the early twenties nationalism started to grow its roots in the Balkans. The rise of nationalism as a dominant ideology influenced Balkan intellectuals and paved the way towards uprisings in Balkan territories. There had always been tension between the Ottoman State and its Christian subjects for a long time. The weakening of the Ottoman army and rise of nationalism served as leverage for many Balkan countries to attempt to gain independence. Russia played a prominent role in the nationalization process with its encouragement of pan-Slavic tendencies among the Slav minorities.

Sencer, Emre, "Balkan Nationalisms in the Ottoman Empire", East European Quarterly, vol. 3, no. 1(2004): pp. 41-64.

After the uprisings in 1884, Serbia, Greece, Romania and Bulgaria disintegrated from the Ottoman State. Later, the political instability in the Balkans and the transformation of the Ottoman ideal to a more Turkishness based identity geared Macedonia and Albania, despite their formidable Muslim populations, to slip away from the Ottoman State.

Identity crisis of Ottoman nationalism precipitated the disintegration of the Muslim unity. Like other nationalist movements throughout the Ottoman State, the idea of Turkish nationalism began to gain momentum in the second half of the nineteenth century through the policies of Young Turks. With its Western-educated leaders, Young Turks re-interpreted the idea of Ottomanism as to highlight Turkish nationality as the nationality of the State. They wanted subjects of the State from different ethnic groups to be merged on the basis of 'Turkishness'.

Ulker, Erol, Contextualising 'Turkification': nationbuilding in the late Ottoman Empire, 1908-1918, Nations and Nationalism, vol.1, no.4 (2005): pp. 613-636.

Their nationalist inclinations fuelled the uprisings rampant around the Ottoman State. 
As the brief historical background presents, nationalist ideas penetrated the Muslim world by the means of intellectuals, education and state policies. It's devastating impacts still dominate Muslim states and impair the vision of ummah.

2 Yunus: 10/10.

3 There are many ahadith about the importance and merits of greeting (salam) in Islam such as:

Narrated By 'Abdullah bin 'Amr: A Man asked the Prophet, "What sort of deeds or (what qualities of) Islam are good?" The Prophet replied, "To feed (the poor) and greet (give salam) those whom you know and those whom you do not know."

(al-Bukhāry, Muḥ ammad Bin Ismāe īl, Șaḥ̄ḥ al-Bukhāry, Ed. Muṣ ț afā Dīb alBughā, (Bayrūt: Dār Ibn Kathīr al-Yamāma, 3rd edition, n.d), 1/13, hadith no: 12; AlQushayrī, Muslim Bin Ḥajjāj. S ậ̣̣h Muslim. Ed. Muḥ ammad Fu'ad' Abd al-Bāqī, (Bayrūt: Dār Ihyā al-Turath al- ' Arabī) 1/65, hadith no: 39)

Narated By Al-Bara' bin 'Azib: Allah's Apostle ordered us to do seven things. He ordered us: to follow the funeral procession. to visit the sick, to accept invitations, to help the oppressed, to fulfil the oaths, to return the greeting and to reply to the sneezer: saying, "May Allah be merciful on you," provided the sneezer says, "All the praises are for Allah."

(Al-Bukhārī: 5/2302, hadith no: 5881; Muslim: 3/1635, hadith no: 2066)

4 Yunus: 10/25.

5 Yunus: 10/25.

6 Anfal: 8/61.

7 Bakara: 2/208.

8 Hujurāt 49/13.

9 Bakara: 2/30.

10 See, Al-Isfahān̄̄, Abū al-Qāsim al-Husayn Bin Muḥ ammad, Al-Mufradāt F̄̄ Garīb al-Qur'ān. Ed. Muḥ ammad Sayyid Kīylān̄i, (Bayrūt: Dār al-Ma'c rifah) p. 156.

11 Enam: 6/165.

12 Sād: 38/26.

13 An'am 6/2.

14 Hijr 15/26.

15 Rahman 55/14.

16 As-Sajdah: 32/7-9.

17 Sād: 38/71-72.

18 Hijr: 15/29. 
19 Ash-Shams: 91/8.

20 Al-Bukhārī: 1/465, hadith no: 1319; Muslim: 4/2047, hadith no:2658.

21 Ibn Kathīr, Ismā̄ il Bin ' Umar, al-Bidāyah wāl-Nihāyah, Bayrūt: Maktabah al$\mathrm{Ma}^{\mathrm{c}}$ ārif, vol. 1, p.115.

22 Muslim, 4/1987, hadith no: 2564.

23 Muslim, 4/1986, hadith no: 2564.

24 Al-Tirmizī, Mụ̣ ammad Bin ' īsā, Sunan al-Tirmizī, Ed. Aḥ mad Muḥ ammad Shākir, (Bayrūt: Dār Iḥ yā al-Turath al-Arabī), 5/734. hadith no: 3955.

25 Muslim, 3/1476. hadith no: 1848, Ibn Ḥibbān, Mụ̣ ammad Bin Ạ̣ mad Abū Ḥātim, S ahīh Ibn Hibbān, Ed. Shuayb al-Arnawūt. (Bayrūt: Muassasat alRisālah, 2nd edition, 1993). 10/441. hadith no: 4580.

26 Ibn Ḥajar, Ah mad bin 'Alī, al-Iș ābat fì Tamyīzi al-ṣaḥāba, Ed. ' Ali Muh ammad al-Bukhāry, (Bayrūt: Dār Jīl, 1th edition, 1414), 3/141, Ibn Al Asīr, Usudu'l Ghāba, 1/462.

27 See, Muḥ ammad bin Aḥ mad al-Qurț ubi. al-Jām ' Lī Aḥ kām al-Qư’’ān, Ed. Aḥ mad Abdul Alīm Al-Bardūnī, (Qāhira: Dār al-Kutub al-Misriyya, 1st edition), $16 / 347$.

28 Ibn Ḥajar Al-Askalānī, 7/738-739, Ibn Al Asīr, 3/375.

29 Ibn Ḥajar Al-Askalān̄̄, 4/118.

30 Mu'minun: 23/101. 